\title{
The contrasting effects of progesterone and oestrogen on the susceptibility of mice to genital infection with Mycoplasma pulmonis
}

\author{
P. M. FURR and D. TAYLOR-ROBINSON
}

Division of Sexually Transmitted Diseases, MRC Clinical Research Centre, Watford Road, Harrow, Middlesex HA1 3 US

\begin{abstract}
Summary. The genital tract of young female mice was rendered susceptible to colonisation with Mycoplasma pulmonis by pre-treating them with progesterone (usually $2.5 \mathrm{mg}$ ) given subcutaneously at weekly intervals for 4 weeks. Colonisation was influenced by the size of the inoculum and by the dose of progesterone; at least $2.5 \times 10^{4}$ organisms and at least $0.5 \mathrm{mg}$ of hormone (administered on four occasions) were required. The duration of colonisation was related also to the size of the inoculum and the dose of progesterone. Similar results were obtained in TO, BALB/c and CBA strains of mice. Progesterone treatment induced the dioestrous stage of the reproductive cycle within 5 days and the cycle of the majority of untreated, mycoplasma-susceptible mice was also at this stage. However, mice, particularly of the CBA strain, were far less susceptible when not given progesterone and the mycoplasmas tended to persist for a shorter time. Mice treated with oestradiol, even in small doses, became completely refractory to infection with $M$. pulmonis. In vitro, progesterone inhibited the growth of $M$. pulmonis, as did oestradiol, but vaginal washings from progesterone-treated mice were no more inhibitory than those from untreated mice. Thus, the success of progesterone in enhancing colonisation could not be attributed to a direct stimulatory effect of the hormone at the mucosal surface and we suggest that it may be due to a greater availability of progesterone-induced receptors for mycoplasmas in the dioestrous phase of the reproductive cycle than in the oestrous phase.
\end{abstract}

\section{Introduction}

Mycoplasma pulmonis is a frequent pathogen in the murine respiratory tract, but it infects the genital tract of mice less often. ${ }^{1}$ However, we showed previously that the genital tract of female mice was rendered more susceptible to infection with this mycoplasma after they had been treated with progesterone." The hormone arrested the rer. oductive cycle in the dioestrous stage, in which vaginal smears contain almost exclusively polymorphonuclear leucocytes (PMNL). In contrast, oestradiol induces cessation of the cycle at the oestrous stage which, cytologically, is characterised by enucleated cornified epithelial cells. The latter hormone predisposed mice to genital infection with Ureaplasma trealyticum, ${ }^{3.4}$ and $M$. hominis, ${ }^{5.6}$ but administration of oestradiol during the course of $M$. pulmonis infection stimulated by progesterone resulted in rapid elimination of the organisms from the genital tract. ${ }^{7}$ In this study, we have considered in more detail the contrasting effects of progesterone and oestradiol on the susceptibility of the genital tract of female mice to $M$. pulmonis, in an attempt to understand the mechanisms whereby progesterone enhances infection by this mycoplasma.

\section{Materials and methods}

Mice

Young adult female mice, 8-10 weeks old, were used. They comprised BALB/c, TO and CBA strains, bred in the Specific Pathogen Free Unit at the Clinical Research Centre and were screened for indigenous mycoplasmas before use.

\section{Hormone treatment}

Progesterone (Depo-provera; Upjohn Ltd, Crawley, West Sussex) $2.5 \mathrm{mg}$, or oestradiol benzoate (Intervet UK, Science Park, Milton Road, Cambridge) $0.5 \mathrm{mg}$ or $0.05 \mathrm{mg}$, were administered subcutaneously at weekly intervals on four occasions.

\section{Médium}

The glucose-containing medium used for the growth 
and isolation of $M$. pulmonis has been described previously. ${ }^{8}$

\section{Inoculum and inoculation}

The JB strain of $M$. pulmonis was obtained originally from Dr J. G. Tully (National Institutes of Health, Bethesda, MD, USA) and had been passed in vitro a further four times in this laboratory. Each mouse received $50 \mu$ l of a suspension that contained $2.5 \times 10^{7}$ viable $M$. pulmonis organisms, except where indicated otherwise; the inoculum was introduced into the vagina by a Finnpipette (Labsystems Og, Pulttitie 8, 00880 Helsinki, Finland). This procedure coincided with the second inoculation with progesterone or, in some experiments, with oestradiol.

\section{Vaginal cytology}

A nasopharyngeal swab (MW142; Medical Wire and Equipment Co., Corsham, Wilts) was inserted into the mouse vagina, rotated to abraid cells and rolled along a microscope slide. The smear was airdried, fixed in methanol, stained by Giemsa's method and observed microscopically-the stage of the reproductive cycle being determined according to the cytological criteria of Rugh. ${ }^{9}$

\section{Collection of vaginal secretions}

A 50- $\mu$ l volume of phosphate-buffered saline (PBS) was introduced into the murine vagina with a Finnpipette; it" was recovered, re-introduced and then collected. This procedure was repeated with a second volume of PBS, thereby providing approximately 100 $\mu \mathrm{l}$ of washing/mouse. The washings from each group of 10 mice (progesterone-treated, oestradiol-treated and untreated) were pooled and centrifuged in a Super Minor bench centrifuge (MSE) at $1000 \mathrm{rpm}$ for $5 \mathrm{~min}$. The supernates from the three groups were passed through $0 \cdot 45-\mu \mathrm{m}$ Swinnex (Millipore) filters to remove any bacteria.

\section{Estimation of number of viable mycoplasmas}

After collection of the sample for cytological examination, the swab was again inserted into the vagina and its contents were expressed in $1.8 \mathrm{ml}$ of mycoplasma growth medium, which was then regarded as a 10 -fold dilution. Further 10 -fold dilutions to $10^{8}$ were prepared, and the cultures were incubated at $37^{\circ} \mathrm{C}$. They were observed daily for a characteristic change in the colour of the medium from red to yellow and the highest dilution to show this change was deemed to contain one colour-changing unit (ccu) and was recorded as the titre of the isolate. The majority of these isolates were assumed to be $M$. pulmonis, but a few were actually identified as such by means of the growth-inhibition technique. ${ }^{10}$
Colonisation of a mouse by $M$. pulmonis was deemed to have occurred if a substantial number of organisms $\left(\geqslant 10^{4} \mathrm{ccu}\right)$ was recovered from the vagina at least 7 days after inoculation. Persistence was defined as recovery of organisms for several weeks.

\section{Estimation of the effect of hormones or vaginal washings directly on $M$. pulmonis}

The hormones and vaginal washings were examined by a metabolism-inhibition test. ${ }^{11}$ Briefly, serial dilutions of the hormones or washings were made in mycoplasmal medium in microtitration plates, to which an equal volume of medium containing $5 \times$ $10^{4} \mathrm{ccu}$ of $M$. pulmonis was added. The plates were sealed and incubated at $37^{\circ} \mathrm{C}$ and observed for the characteristic change in colour of the medium from red to yellow. Mycoplasmal growth-promoting activity of hormones or washings would be denoted by colour changes occurring more rapidly in wells containing these components than in those containing medium only. Conversely, growth inhibition would be denoted by the absence of colour changes in wells containing the hormones or washings, or by such changes occurring less rapidly than in those containing medium only.

\section{Results}

Effect of various doses of progesterone on colonisation by $M$. pulmonis

The dose of progesterone required to enhance vaginal colonisation by $M$. pulmonis was determined in BALB/c and TO strains of mice that had received $2.5 \times 10^{7}$ organisms (table I). A dose of $0.5 \mathrm{mg}$ was the least that resulted in colonisation of and persistence in a majority of the mice of either strain and BALB/c mice appeared slightly more sensitive in this regard than did TO mice.

\section{Effect of various doses of $M$. pulmonis and of progesterone on colonisation by $M$. pulmonis}

Inocula containing $>2.5 \times 10^{4} \mathrm{ccu}$ of $M$. pulmonis were the most effective in causing colonisation and persistence in mice that received either $2.5 \mathrm{mg}$ or $1.0 \mathrm{mg}$ of progesterone (table II). Half of the mice which were not treated with the hormone were colonised when given $2.5 \times 10^{8}$ organisms but not when given a smaller inoculum. None of the mice in any group was colonised after receiving $2.5 \times 10^{2}$ organisms (data not shown).

\section{Effect of mouse strain and progesterone treatment on} colonisation by $M$. pulmonis

The susceptibility to colonisation by M.pulmonis of TO, BALB/c and CBA strains of mice after treatment 
Table I. Dose of progesterone required to predispose mice to vaginal colonisation by M. pulmonis

\begin{tabular}{|c|c|c|c|c|c|c|}
\hline \multirow{2}{*}{$\begin{array}{l}\text { Amount of } \\
\text { progesterone } \\
(\mathrm{mg})^{*}\end{array}$} & \multirow{2}{*}{$\begin{array}{l}\text { Mouse } \\
\text { strain }\end{array}$} & \multicolumn{5}{|c|}{$\begin{array}{l}\text { Number of mice colonised (GMT)/group of } 10 \text { on } \\
\text { indicated day after inoculation with } M \text {. pulmonist }\end{array}$} \\
\hline & & 7 & 21 & 42 & 81 & 104 \\
\hline 2.5 & $\begin{array}{l}\mathrm{BALB} / \mathrm{c} \\
\text { TO }\end{array}$ & $\begin{array}{l}10\left(6 \times 10^{6}\right) \\
10\left(2 \times 10^{6}\right)\end{array}$ & $\begin{array}{l}10\left(5 \times 10^{6}\right) \\
10\left(1 \times 10^{7}\right)\end{array}$ & $\begin{array}{l}10\left(2 \times 10^{6}\right) \\
10\left(3 \times 10^{6}\right)\end{array}$ & $\begin{array}{r}8 \ddagger\left(1 \times 10^{6}\right) \\
5\left(6 \times 10^{2}\right)\end{array}$ & $\begin{array}{c}8 \ddagger\left(6 \times 10^{5}\right) \\
\text { ND }\end{array}$ \\
\hline 1.0 & $\begin{array}{l}\mathrm{BALB} / \mathrm{c} \\
\text { TO }\end{array}$ & $\begin{array}{l}10\left(1 \times 10^{7}\right) \\
10\left(2 \times 10^{6}\right)\end{array}$ & $\begin{array}{l}10\left(8 \times 10^{6}\right) \\
10\left(6 \times 10^{6}\right)\end{array}$ & $\begin{array}{r}10\left(3 \times 10^{5}\right) \\
9\left(8 \times 10^{4}\right)\end{array}$ & $\begin{array}{l}8\left(1 \times 10^{4}\right) \\
1\left(4 \times 10^{\prime 1}\right)\end{array}$ & $\begin{array}{c}6\left(3 \times 10^{3}\right) \\
\text { ND }\end{array}$ \\
\hline 0.5 & $\begin{array}{l}\mathrm{BALB} / \mathrm{c} \\
\text { TO }\end{array}$ & $\begin{array}{r}10\left(3 \times 10^{6}\right) \\
7\left(4 \times 10^{4}\right)\end{array}$ & $\begin{array}{r}10\left(6 \times 10^{6}\right) \\
6\left(5 \times 10^{3}\right)\end{array}$ & $\begin{array}{l}10\left(1 \times 10^{5}\right) \\
\text { ND }\end{array}$ & $\begin{array}{l}6\left(2 \times 10^{2}\right) \\
2\left(2 \times 10^{1}\right)\end{array}$ & $\begin{array}{l}1\left(5 \times 10^{1}\right) \\
\text { ND }\end{array}$ \\
\hline 0.25 & $\begin{array}{l}\mathrm{BALB} / \mathrm{c} \\
\text { TO }\end{array}$ & $\begin{array}{l}3\left(1 \times 10^{2}\right) \\
3\left(8 \times 10^{11}\right)\end{array}$ & $\begin{array}{l}3\left(5 \times 10^{1}\right) \\
3\left(4 \times 10^{1}\right)\end{array}$ & $\begin{array}{l}2\left(8 \times 10^{6}\right) \\
0\end{array}$ & $\begin{array}{l}1\left(5 \times 10^{y}\right) \\
0\end{array}$ & $\begin{array}{c}0_{+}^{+} \\
\mathrm{ND}\end{array}$ \\
\hline $\mathrm{Nil}$ & $\begin{array}{l}\mathrm{BALB} / \mathrm{c} \\
\mathrm{TO}\end{array}$ & $\begin{array}{l}4\left(2 \times 10^{1}\right) \\
3\left(5 \times 10^{1}\right)\end{array}$ & $\begin{array}{l}3\left(3 \times 10^{2}\right) \\
2\left(4 \times 10^{\circ}\right)\end{array}$ & $\begin{array}{l}0 \\
2\left(5 \times 10^{4}\right)\end{array}$ & $\begin{array}{l}0 \\
0\end{array}$ & $\begin{array}{ll}0 & \\
& \text { ND }\end{array}$ \\
\hline
\end{tabular}

ND, not done. GMT, geometric mean titre.

* In each of four doses at weekly intervals.

$+2.5 \times 10^{7}$ organisms $(\mathrm{ccu})$ intravaginally.

¥ In a group of nine mice.

Table II. Number of $M$. pulmonis organisms required to colonise TO mice given different amounts of progesterone

\begin{tabular}{|c|c|c|c|c|c|}
\hline \multirow{2}{*}{$\begin{array}{l}\text { Amount of } \\
\text { progesterone } \\
(\mathrm{mg})^{*}\end{array}$} & \multirow{2}{*}{$\begin{array}{l}\text { Number of organisms } \\
\text { inoculated }\end{array}$} & \multicolumn{4}{|c|}{$\begin{array}{l}\text { Number of mice colonised (GMT)/group } \\
\text { of } 10 \text { on indicated day after inoculation }\end{array}$} \\
\hline & & 7 & 21 & 35 & 84 \\
\hline \multirow[t]{3}{*}{2.5} & $2.5 \times 10^{8}$ & $\begin{array}{c}10 \\
3 \times 10^{6}\end{array}$ & $\begin{array}{r}9 \dagger \\
1 \times 10^{7}\end{array}$ & $\begin{array}{r}9 \dagger \\
2 \times 10^{6}\end{array}$ & $\begin{array}{r}6 \dagger \\
1 \times 10^{3}\end{array}$ \\
\hline & $2.5 \times 10^{6}$ & $\begin{array}{c}10 \\
1 \times 10^{6}\end{array}$ & $\begin{array}{c}10 \\
8 \times 10^{6}\end{array}$ & $\begin{array}{c}10 \\
4 \times 10^{6}\end{array}$ & $3 \times 10^{1}$ \\
\hline & $2.5 \times 10^{4}$ & $2 \times \stackrel{4}{10^{2}}$ & $3 \times 10^{2}$ & $4 \times{ }^{4} 0^{2}$ & $\begin{array}{c}2 \\
4 \times 10^{\circ}\end{array}$ \\
\hline \multirow[t]{3}{*}{$1 \cdot 0$} & $2.5 \times 10^{A}$ & $\begin{array}{c}9 \\
5 \times 10^{1}\end{array}$ & $5 \times 10^{4}$ & $\begin{array}{c}6^{+} \\
2 \times 10^{3}\end{array}$ & $4 \times 10^{3+}$ \\
\hline & $2.5 \times 10^{6}$ & $\begin{array}{c}7 \\
3 \times 10^{4}\end{array}$ & $8 \times{ }^{7} 0^{4}$ & $\begin{array}{c}7 \\
1 \times 10^{4}\end{array}$ & $\begin{array}{c}1 \\
4 \times 10^{0}\end{array}$ \\
\hline & $2.5 \times 10^{4}$ & $\begin{array}{c}5 \\
2 \times 10^{3}\end{array}$ & $\begin{array}{r}5 \dagger \\
3 \times 10^{3}\end{array}$ & $\begin{array}{r}5 \dagger \\
3 \times 10^{3}\end{array}$ & $\begin{array}{c}3 \dagger \\
2 \times 10^{1}\end{array}$ \\
\hline \multirow[t]{2}{*}{$\mathrm{Nil}$} & $2.5 \times 10^{*}$ & $8 \times \sqrt[5]{10^{1}}$ & $1 \times 10^{2}$ & $8 \times \stackrel{4}{10}^{1}$ & 0 \\
\hline & $2.5 \times 10^{6}$ & $3 \times 10^{0}$ & $3 \times 10^{0}$ & 0 & 0 \\
\hline
\end{tabular}

GMT, geometric mean titre.

* In each of four doses at weekly intervals.

+ In a group of nine mice.

$\ddagger$ In a group of eight mice

with progesterone $(2.5 \mathrm{mg}$ doses $)$ was assessed in several experiments (table III). Mice of strains TO and $\mathrm{BALB} / \mathrm{c}$, whether treated with progesterone or not, were affected similarly; the progesterone-treated mice were susceptible to $M$. pulmonis at least twice as frequently as the untreated ones and their colonisation persisted longer. The progesterone-treated CBA mice responded in a similar way to the other hormonetreated strains but the untreated CBA mice were the least susceptible of any and colonisation did not persist in any of these mice beyond the first week.
Effect of progesterone and oestradiol on susceptibility to M. pulmonis

In a further experiment (table IV), the susceptibility to $M$. pulmonis of BALB/c mice that had received progesterone $(2.5 \mathrm{mg}$ doses) was enhanced, as before, when compared with the susceptibility of mice that did not receive any hormone treatment. In contrast, administration of oestradiol $(0.5 \mathrm{mg}$ doses) resulted in fewer mice becoming colonised than in even the untreated mice. Furthermore, smaller numbers of 
Table III. Vaginal colonisation with $M$. pulmonis of different strains of mice treated or not treated with progesterone*

\begin{tabular}{|c|c|c|c|c|c|}
\hline \multirow{2}{*}{$\begin{array}{l}\text { Mouse } \\
\text { strain }\end{array}$} & \multirow{2}{*}{$\begin{array}{l}\text { Progesterone } \\
\text { treatment }\end{array}$} & \multicolumn{4}{|c|}{$\begin{array}{l}\text { Number of mice colonised/number challenged }(\%) \text { on } \\
\text { indicated day after inoculation with } M \text {. pulmonis } \dagger\end{array}$} \\
\hline & & 7 & 28 & 42 & 112 \\
\hline TO & $\begin{array}{l}+ \\
-\end{array}$ & $\begin{array}{c}113 / 115(98 \%) \\
35 / 75(47 \%)\end{array}$ & $\begin{array}{l}35 / 35(100 \%) \\
18 / 35(51 \%)\end{array}$ & $\begin{array}{r}99 / 113(88 \%) \\
14 / 74(19 \%)\end{array}$ & $\begin{array}{l}9 / 15(60 \%) \\
0 / 14 \quad \cdots\end{array}$ \\
\hline $\mathrm{BALB} / \mathrm{c}$ & + & $\begin{array}{l}40 / 40(100 \%) \\
10 / 20(50 \%)\end{array}$ & $\begin{array}{l}40 / 40(100 \%) \\
10 / 20(50 \%)\end{array}$ & $\begin{array}{c}40 / 40(100 \%) \\
6 / 20(30 \%)\end{array}$ & $\begin{array}{r}25 / 45(63 \%) \\
5 / 20(25 \%)\end{array}$ \\
\hline CBA & + & $\begin{array}{r}14 / 15(93 \%) \\
4 / 14(29 \%)\end{array}$ & $\begin{array}{c}14 / 15(93 \%) \\
0 / 14 \quad \cdots\end{array}$ & $\begin{array}{c}14 / 15(93 \%) \\
0 / 14 \quad \cdots\end{array}$ & $\begin{array}{l}\text { ND } \\
\text { ND }\end{array}$ \\
\hline
\end{tabular}

ND, not done.

$* 2.5 \mathrm{mg}$ in each of four weekly doses.

$+2.5 \times 10^{6}-2.5 \times 10^{8}$ organisms (ccu) intravaginally.

Table IV. The effects of progesterone compared with those of oestradiol and of no hormone treatment on vaginal colonisation of BALB/c mice with $M$. pulmonis

\begin{tabular}{l|cccc}
\hline \multirow{2}{*}{ Treatment } & \multicolumn{4}{|c}{$\begin{array}{c}\text { Number of mice colonised (titre range) and GMT/group of } 10 \\
\text { on indicated day after inoculation of M.pulmonis }\end{array}$} \\
\cline { 2 - 5 } & 7 & 21 & 42 & 105 \\
\hline $\begin{array}{c}\text { Progesterone } \\
(2.5 \mathrm{mg}) \dagger\end{array}$ & 10 & 10 & 10 & 10 \\
& $\left(10^{5}-10^{8}\right)$ & $\left(10^{6}-10^{9}\right)$ & $\left(10^{4}-10^{7}\right)$ & $\left(10^{2}-10^{7}\right)$ \\
Oestradiol & $3 \times 10^{6}$ & $2 \times 10^{7}$ & $3 \times 10^{6}$ & $3 \times 10^{5}$ \\
$(0.5 \mathrm{mg}) \dagger$ & 2 & 2 & 1 & 2 \\
& $\left(10^{2}-10^{6}\right)$ & $\left(10^{3}-10^{7}\right)$ & $\left(10^{7}\right)$ & $\left(10^{3}-10^{5}\right)$ \\
None & $6 \times 10^{1}$ & $1 \times 10^{2}$ & $5 \times 10^{1}$ & $6 \times 10^{1}$ \\
& 6 & 6 & 6 & 5 \\
& $\left(10^{5}-10^{6}\right)$ & $\left(10^{3}-10^{7}\right)$ & $\left(10^{5}-10^{8}\right)$ & $\left(10^{3}-10^{6}\right)$ \\
& $2 \times 10^{3}$ & $1 \times 10^{3}$ & $4 \times 10^{3}$ & $3 \times 10^{2}$ \\
\hline
\end{tabular}

+ In each of four doses at weekly intervals.

organisms were recovered from the oestradiol-treated than from either of the other two groups of mice. The inhibitory effect of oestradiol was emphasised further by the finding (data not shown) that an even smaller dose $(0.05 \mathrm{mg})$ was inhibitory to vaginal colonisation by $M$. pulmonis. Thus, none of $10 \mathrm{TO}$ mice so treated became colonised (negative at 7 days), whereas two of 10 untreated mice and all of 10 progesterone-treated mice did so.

\section{Effect of hormones on the stage of the reproductive cycle}

As shown in table V, 2 days after the administration of progesterone, the reproductive cycle of five mice had arrested at the dioestrous stage and that of the remaining five mice had reached this stage within 5 days and remained there. However, the effect of oestradiol was much slower. Thus, although seven mice were in the oestrous stage after 2 days, reversion to the pro-oestrous or post-oestrous stages was seen occasionally and complete conversion to the oestrous stage was not seen until almost 1 month. Untreated mice continued to cycle in the expected manner (table V).
Influence of the stage of the reproductive cycle on susceptibility of hormone-untreated mice to colonisation by $M$. pulmonis

In the previous experiments (tables I-IV), some mice that had not been treated with either hormone became colonised with $M$. pulmonis, the proportion varying a little in different experiments. The stage of the reproductive cycle at which colonisation was most likely to occur was assessed. The results (table VI) showed that mice in the dioestrous stage when they were given the mycoplasma inoculum were about twice as likely to become colonised as mice that were in other stages of the cycle.

\section{Effect of hormones and vaginal washings on $M$. pulmonis in vitro}

The effect of progesterone and of oestradiol directly on $M$. pulmonis was determined in a metabolisminhibition test. The effect of vaginal washings from mice treated with these hormones and from untreated mice was determined in the same way. Neither hormone stimulated the growth of $M$. pulmonis. Indeed, both progesterone and oestradiol at concentrations of 
Table V. Effect of progesterone or oestradiol on the murine reproductive cycle

\begin{tabular}{|c|c|c|c|c|c|c|c|c|c|}
\hline \multirow{2}{*}{$\begin{array}{l}\text { Hormone given and } \\
\text { stage of cycle }\end{array}$} & \multicolumn{9}{|c|}{$\begin{array}{l}\text { Number of mice/group of } 10 \text { at each stage of the } \\
\text { reproductive cycle on indicated day after hormone treatment }\end{array}$} \\
\hline & $0^{*}$ & 2 & 5 & $7^{*}$ & 12 & $14^{*}$ & 19 & $21^{*}$ & 26 \\
\hline \multicolumn{10}{|l|}{ Progesterone } \\
\hline Early oestrous & 3 & - & - & - & - & - & - & - & - \\
\hline Oestrous & 3 & 1 & - & - & - & - & - & - & - \\
\hline Post-oestrous & 1 & 4 & - & - & - & - & - & - & - \\
\hline Dioestrous & 3 & 5 & 10 & 10 & 10 & 10 & 10 & 10 & 10 \\
\hline Pro-oestrous & - & - & - & - & - & - & - & - & - \\
\hline \multicolumn{10}{|l|}{ Oestradiol } \\
\hline Early oestrous & 2 & 2 & 1 & 2 & - & - & - & - & - \\
\hline Oestrous & 3 & 7 & 5 & 5 & 4 & 4 & 9 & 8 & 10 \\
\hline Post-oestrous & 1 & 1 & 4 & - & 3 & 4 & 1 & - & - \\
\hline Dioestrous & 4 & - & - & - & - & - & - & 1 & - \\
\hline Pro-oestrous & - & - & - & 3 & 3 & 2 & - & 1 & - \\
\hline \multicolumn{10}{|l|}{ None } \\
\hline Early oestrous & 3 & - & 2 & 2 & 1 & 2 & 3 & - & - \\
\hline Oestrous & 2 & 5 & 1 & 5 & 2 & 3 & 1 & 4 & 5 \\
\hline Post-oestrous & 3 & 3 & 3 & 2 & 3 & - & 2 & 2 & 1 \\
\hline Dioestrous & 1 & 2 & 4 & 1 & 4 & 5 & 3 & 4 & 2 \\
\hline Pro-oestrous & 1 & - & - & - & - & - & 1 & - & 2 \\
\hline
\end{tabular}

* Day on which hormone was injected.

Table VI. The susceptibility to $M$. pulmonis of hormoneuntreated mice in different stages of the reproductive cycle

\begin{tabular}{lc|cc}
\hline \multirow{2}{*}{$\begin{array}{l}\text { Mouse } \\
\text { strain }\end{array}$} & $\begin{array}{c}\text { Number of } \\
\text { mice inoculated }\end{array}$ & \multicolumn{2}{|c}{$\begin{array}{c}\text { Proportion of mice colonised during } \\
\text { indicated stage of the cycle }\end{array}$} \\
& & Dioestrous & Other stages \\
\hline TO & 21 & $2 / 7$ & $2 / 14$ \\
BALB/c & 19 & $3 / 8$ & $1 / 11$ \\
CBA & 24 & $4 / 5$ & $5 / 19$ \\
Total & 64 & $9 / 20(45 \%)$ & $8 / 44(18 \%)$ \\
\hline
\end{tabular}

* $2.5 \times 10^{7}$ organisms (ccu) intravaginally.

$\geqslant 156 \mu \mathrm{g} / \mathrm{ml}$ and $\geqslant 7.8 \mu \mathrm{g} / \mathrm{ml}$, respectively, inhibited growth of the mycoplasma. However, the inhibitory activity of vaginal washings from mice treated with either hormone was no greater than that of washings from untreated mice.

\section{Discussion}

Unlike progesterone, oestradiol does not enhance infection of the murine genital tract by $M$. pulmonis. Indeed. it has an inhibitory effect on colonisation, even when given in small doses, this being associated with stabilisation of the reproductive cycle in the oestrous stage. The inhibitory effect could be due to competition between $M$. pulmonis and other bacteria for cell receptors, as it is known that the naturally occurring bacterial flora proliferate within the vagina following the administration of oestradiol. ${ }^{12}$ However, overgrowth of the endogenous flora does not impede colonisation by $U$. urealyticum ${ }^{3.4}$ or $M$. hominis ${ }^{5}$ in oestradiol-treated mice. Therefore, it seems more likely that the failure of oestradiol to promote colonisation by $M$. pulmonis would be due to a lack of appropriate host cell receptors for this mycoplasma than to competitive inhibition. In contrast to the effect of oestradiol, progesterone treatment enhances both colonisation and subsequent persistence, the organisms being recovered for long periods. The effect of progesterone is dose dependent, $<0.5 \mathrm{mg}$ being suboptimal or ineffective, and is associated with the reproductive cycle being converted rapidly to and maintained in the dioestrous stage. Support for the important influence of the dioestrous stage comes from the fact that mice that are not treated with hormone are most susceptible to $M$. pulmonis when their natural cycle is in the dioestrous stage. Generally, persistence of the organisms in untreated mice was of relatively short duration, presumably due to the rapid change to other stages of the cycle that occurs naturally in such mice. We suggest that host receptor cells to which $M$. pulmonis can adhere become more numerous or more accessible during the dioestrous stage, particularly that induced by treatment with progesterone. If such receptor cells are few or less accessible, as in mice not treated with progesterone or given only a small dose of the hormone, organisms introduced in larger numbers are more likely to make contact with these cells and, hence, initiate colonisation, at least for a limited period.

The stimulatory effect of progesterone treatment is unlikely to be due simply to a direct effect of any hormone present in vaginal tissues or secretions because progesterone, like oestradiol, is inhibitory to the multiplication of $M$. pulmonis in vitro. Moreover, vaginal washings from hormone-treated mice had no greater effect on $M$. pulmonis in vitro than did those from untreated mice. These observations are consistent with the proposition that the susceptibility of mice to $M$. pulmonis induced by progesterone is 
receptor cell-based and is brought about by the hormone stabilising the reproductive cycle in the dioestrous stage.

The exact anatomical site of putative receptor cells is unknown. Although $M$. pulmonis organisms were recovered by inserting swabs into the vagina, it is unclear whether vaginal epithelial cells themselves

\section{References}

1. Cassell GH, Hill A. Murine and other small-animal mycoplasmas. In: Tully JG, Whitcomb RF (eds) The mycoplasmas, vol. 2. New York, Academic Press. 1979:235-273.

2. Furr PM, Taylor-Robinson D. Enhancement of experimental Mycoplasma pulmonis infection of the mouse genital tract by progesterone treatment. $J$ Hyg $1984 ; 92$ : 139-144.

3. Iwasaka T, Wada T, Sugimori H. Enhancement of colonization of Ureaplasma urealyticum in the mouse genital tract by estrogen treatment. Am J Obstet Gynecol 1986; 155: 1124-1127.

4. Furr PM, Taylor-Robinson D. The establishment and persistence of Ureaplasma urealyticum in oestradiol-treated female mice. J Med Microbiol 1989; 29: 111-114.

5. Furr PM, Taylor-Robinson D. Oestradiol-induced infection of the genital tract of female mice by Mycoplasma hominis. $J$ Gen Microbiol 1989; 135: 2743-2749.

6. Furr PM, Hetherington CM, Taylor-Robinson D. The susceptibility of germ-free, oestradiol-treated, mice to $\mathrm{Myco}$ plasma hominis. J Med Microbiol 1989; 30 : 233-236. become colonised initially or whether there is colonisation primarily of receptor cells in the higher reaches of the genital tract and the presence of organisms in the vagina results from their downward flow. However, it should be possible to locate the major site of any such receptor cells (e.g., by scanning electron-microscopy), and then determine their nature.

7. Taylor-Robinson D, Furr PM. Elimination of mycoplasmas from the murine genital tract by hormone treatment. Epidemiol Infect 1990; 105: 163-168.

8. Manchee RJ, Taylor-Robinson D. Haemadsorption and haemagglutination by mycoplasmas. J Gen Microbiol 1968 ; 50: $465-478$.

9. Rugh R (ed). The mouse. Its reproduction and development Minneapolis, Burgess Publishing Co. 1968: 38-39.

10. Clyde WA. Mycoplasma species identification based upon growth inhibition by specific antisera. J Immunol $1964 ; 92$ 958-965.

11. Taylor-Robinson D, Purcell RH, Wong DC, Chanock RM. A colour test for the measurement of antibody to certain mycoplasma species based upon the inhibition of acid production. $J$ Hyg 1966; 64: 91-104.

12. Furr PM, Taylor-Robinson D. The influence of hormones on the bacterial flora of the murine vagina and implications for human disease. Microb Ecol Hlth Dis 1991: 4 141-148. 